\title{
Some Remarks on Cheryl Misak's The American Pragmatists
}

Joseph Margolis

\section{CpenEdition}

\section{Journals}

\section{Electronic version}

URL: http://journals.openedition.org/ejpap/548

DOI: $10.4000 /$ ejpap.548

ISSN: 2036-4091

\section{Publisher}

Associazione Pragma

\section{Electronic reference}

Joseph Margolis, "Some Remarks on Cheryl Misak's The American Pragmatists », European Journal of Pragmatism and American Philosophy [Online], V-2 I 2013, Online since 24 December 2013, connection on 23 April 2019. URL : http://journals.openedition.org/ejpap/548; DOI : 10.4000/ejpap.548

This text was automatically generated on 23 April 2019

\section{(c) $\Theta \Theta \Theta$}

Author retains copyright and grants the European Journal of Pragmatism and American Philosophy right of first publication with the work simultaneously licensed under a Creative Commons AttributionNonCommercial-NoDerivatives 4.0 International License. 


\title{
Some Remarks on Cheryl Misak's The American Pragmatists
}

\author{
Joseph Margolis
}

1 I find myself in a small quandary in addressing Cheryl Misak's new book, The American Pragmatists. ${ }^{1}$ The fact is I like the book very much. It's written in an open and sprightly way, scrupulous and immensely useful in joining (what I myself have come to distinguish as) "textualist" and "genealogical" elements (explication de texte and interpretive reconstruction), in fashioning an extremely plausible survey of the entire trajectory of American pragmatism from Chauncey Wright (please note) and Charles Peirce down to Richard Rorty and Hilary Putnam (and a bit beyond). Nevertheless, I'm persuaded that Misak misses the essential key to the best reading of Dewey and Peirce, taken separately and convergently, with regard to the thread of her own account; she follows Bertrand Russell's lead in featuring pragmatism's "theory of truth" (and knowledge), which she explores very carefully indeed in the service of what she argues "is the most defensible pragmatist lineage" (xi-xii). But to rely on the guidance of the "theory of truth" is already to court confusion.

2 I favor Misak's project as far as it goes, though I note, in passing, that James comes off as distinctly second string (on truth and knowledge), however charitably she reads his philosophical labors, and that Rorty (as "contemporary pragmatism's William James" (225)) is effectively obliged to recant nearly the whole of his disquotationism and doctrine of epistemic and normative solidarity. She makes the case against both as neatly and as tellingly as any summary I've seen: she has a very good eye for textual economy and accuracy across a sprawling literature. I have no quarrel with her assessment of James, and I agree that James's problematic corrections of his own disastrous first sortie regarding the definition of truth and the abiding "awkwardness" (Misak's term) of Dewey's treatment of what, famously, he calls (in his Logic) a "problematic situation" recast in The Quest for Certainty (in a way meant to signal the essential pragmatist themes he shares with Peirce) - remain the principal sites of the deep weakness (the perceived weakness) of the classic phase of pragmatism's standing in the new century. 
3 I take Misak to be recommending that we let James swim for himself and that we concede (as we must) that Dewey never quite gets it right (philosophically) in explicating his "problematic situation" - the key to his attempt to distinguish pragmatism from untenable forms of realism and idealism; and that, accordingly, we should adopt Peirce's resolution of the pragmatist puzzle (which Dewey ultimately, though mistakenly, believes he's pretty well already adopted). I believe Misak is very close to reading Dewey's "awkward" analysis correctly, but in the end, somehow, she does not succeed. She cites Dewey's solution - repeatedly - but misreads the lesson; misled thus, she misses the essential convergence between Peirce and Dewey - and thus, pragmatism's corrective contribution. I also think she produces her own unwanted paradoxes in her reading of Peirce. The point of her account (which I support, if I understand it rightly, read in the spirit of her previous books and papers), not her actual account, is to lay bare the strongest version of the pragmatist commitment to realism (serving both science and practical life: accommodating the "truths" and forms of "knowledge" of ethics and language and mathematics, as well as of the empirical sciences, within a reasonably articulated naturalism), wherever the rest of recent analytic philosophy remains largely unpersuaded by late pragmatism's recuperative work. Here, of course, she addresses Richard Rorty's often careless (often finally rescinded) infelicities, which, unquestionably, have muddled any favorable appraisal of pragmatism's philosophical fortunes. The truth is Rorty nearly seals the conventional reading of pragmatism's general unreliability. Misak reads Rorty's errors as redirecting us to Peirce. (But Rorty pretty well dismisses Peirce).

In any case, reading Misak, I dare say I spy what still needs to be made explicit in any sensible interpretation of Dewey's texts - which have in fact still eluded nearly all analytically-minded readers of Dewey, and including Holmes, Peirce, Royce, Russell, James, Perry, Nagel, and Misak herself - which, let it be said, may be straightforwardly clarified in the light of Dewey's own texts: because Dewey makes the effort himself, however obscurely others have found his argument to be. If I'm right, Dewey demonstrably succeeds in strengthening the pragmatists's best prospects in a distinctive way that regularly strengthens our reading of Peirce. I find a knockdown cluster of clues in Dewey, all of which Misak touches on - but misreads. Once you grasp their import, you realize that they're ubiquitous in Dewey's texts, though, quite possibly, they were always too "awkwardly" phrased (more likely, inserted too early among the arguments of an inhospitable academy) to have been spotted without a better clue, which Misak again supplies but fails to fathom.

5 I shall have to collect the argument in the sparest way to capture all of its ingenuity and philosophical force. Let me begin by saying that I actually attended Ernest Nagel's lectures (at Columbia) on Dewey's Logic, early in the 1950s (it must have been), when Nagel rather deftly (but somehow not compellingly) ridiculed Dewey's phrasing of the familiar claim (which Misak cites, together with earlier remarks of Nagel's, which she pretty clearly accepts as decisive). Here are some of Dewey's best-known formulations, which I gloss opportunistically:

Personal states of doubt that are not evoked by and are not relative to some existential situation are pathological... a withdrawal from reality. (124-5)

6 This is Dewey's answer to Bertrand Russell, which Russell could never accept or which he saw no way of construing sensibly. 
It is the situation that has these traits. We are doubtful because the situation is inherently doubtful. (124)

7 This is Dewey's "Hegelian" intuition, which is not designed to discredit the dependent (effective) "autonomy" of language and logic with regard to truth.

[The situation is the] interaction of organic responses and environing conditions.

This is Dewey's "Hegelianized" reading of his "Darwinian" treatment of the continuum of experience, within the terms of which reason (language and logic) functions "autonomously," if at all (that is, when applied to the entire range of human practices). ${ }^{2}$

9 I'm afraid Misak's failure, here, confirms her failure to grasp the novelty that Peirce and Dewey effectively share, though they approach matters from very different vantages. I'll come to the details in a moment. But let me say that her "worry" (Peirce's worry as well, Russell's worry, Nagel's worry, even Carus's worry if you read Carus's worry about James, which Misak cites, as inevitably applying to Dewey) concerns the following central issues that remain insufficiently explicated to this day: (i) the conjoined roles of what (in their different ways) Dewey and Peirce draw from Hegelian and Darwinian sources; (ii) the "correct" account of the relationship between naturalism and pragmatism; (iii) the sense in which Peirce and Dewey are willing to concede links to the standard concerns of realism and idealism, without endorsing untenable versions of either, rampant in their day: viz., forms of "realism" that treat our cognitive grasp of the real as "unmediated" or privileged; forms of "idealism" that entail the thesis that the physical world is somehow actually "constructed" by our cognitive interventions; (iv) the conceptual relationship between the distinctive rigor of "reason" (or "thought") and the continuum of "experience" (to include more than "sensory perception": in particular, to include feeling, mood, interest, the whole of practical life, or, as Dewey sometimes says, existential problems); hence, therefore, (v) the parity or primacy (or inseparability) of language and logic addressed to truth-yielding questions about the world, embedded in the entire run of our experience (that is, experienced practices within the world): effectively, what Dewey calls a "situation," the metaphysically heuristic unity of subject and object (if you please) of "the interaction of organic responses and environing conditions" that Dewey makes so much of in his deliberate contrivance meant to preclude every dualism. (Here, notoriously, Rorty thought he spied the "agreement" between Dewey and Heidegger.)

Item (v) is, of course, the ur-site of the contentious contemporary quarrel regarding the defense of classical pragmatism prompted by Rorty's various efforts at promoting the socalled "linguistic" turn. (Of course, here again, though with a vengeance, Rorty reverses himself). ${ }^{3}$

11 Nagel was genuinely baffled by Dewey's idiom. I saw that much in Nagel's efforts to make sense of Dewey's wording. His “worry" apparently never changed from his earlier appraisals rendered in 1939, which Misak reports. Of course, Nagel would have found any "Hegelian" reading of logic to be effectively illiterate and any "Darwinian" entanglement irrelevant. (He was too close to Russell). But that's because - in Columbia-"speak," apart from Russell's influence - Nagel was genuinely more of a "naturalist" than a "pragmatist," which is to say he favored the relative "autonomy" of logic, mathematics, and the physical sciences. But to put the matter thus is to miss the point of Dewey's important innovation. Admittedly, Dewey was out of his depth in this sort of naturalism (which, abstractly, collects Russell, the positivists, and Peirce easily enough). 
Nevertheless, Dewey grasped the ultimate dependence of this sort of autonomy on the amplitude of what he called "experience" - the run of actual human practices that make the autonomy of the other possible at all. Of course, he couldn't express his pragmatistic naturalism in terms of the naturalism of the other; curiously, Peirce was more convincing in naturalizing his own idealist extravagance by way of abductive Hope; though he urges the same sort of dependence.

If I understand Dewey's argument correctly, then he surely meant to abide by Peirce's sense of the proper rigors of formal logic. It's only that Dewey couldn't see (and he was right to insist that no one could) how logic could be pertinent to the analysis of the rationality of ordinary discourse (a fortiori, how the analysis of the rationality of any derived formal language could illuminate our concerns about truth - a matter that, in a way, Tarski confirms), if there is no underlying continuum of "animal" and "enlanguaged" experience (in Dewey's enlarged sense) on which the "autonomous" discipline of logic itself depends. There simply is no logic or language if we cannot locate its functional presence in the existential practices of human life (in experience, as Dewey never tires of insisting). (We, now, more up-to-dately, may extend Dewey's argument to include the "dependent" autonomy of semantic analysis as well, anticipating the potential bearing of Rorty's various arguments about pragmatism's prospects, which Misak very reasonably dissects.) So much for the "language"/ "experience" divide: time is on the pragmatists' side.

I insist, however, that hardly any respectable logician or semantic analyst (short of Frege or the Russell and Wittgenstein that came under Frege's influence) would now dismiss the gist of Dewey's claim: certainly not Sellars or Brandom or Huw Price, and hopefully not successors of Peirce or Nagel, hence not Misak herself. Perhaps Dewey had simply not earned the right to make his charge. Nevertheless, he grasped an essential clue that the "autonomists" ("empiricists" or "intellectualists") were themselves unable to formulate. Let me suggest that it's still very hard to see the compelling force of Dewey's argument if one fails to guess the contrived (the deliberately constructed, the heuristic, the figurative) "advantage" of Dewey's "Hegelian" idiom (or "picture") of the indissoluble union of the subjective and the objective ingredients of thought and world, which (as with Peirce as well) we learn to read in the pragmatist's naturalized way! It's here that Peirce and Dewey converge.

It's here that the advocacy of realism - post-Kant and post-Hegel - cannot neglect to admit the mediation of enlanguaged thought without falling back to representationalism or idealist constructionism. There's the pragmatist contribution the analytic academy still largely fails to discern: the distinction between a heuristic "picture" of the world, the independent world itself, and our commitment to the second on the abductive power of the first. I deliberately draw my counter-argument from Misak's own text, especially where she herself cites Dewey's texts against Dewey's contribution: because Misak is never more than a hair away from the "better reading." Dewey's clue is brilliantly simple and compelling: it may be no more than a variant of Berkeley's profound insight separated from the fatal atomistic "givens" of British empiricism and the absurdity of subjective idealism. Frankly, I can't see how anyone, now, could fail to grasp Dewey's ace. Misak herself says candidly enough: "Dewey hits the nail on the head"; and yet she never gets beyond the verdict:

Dewey's attempt at bringing Hegelian insights to the empiricist or naturalist picture seems always less than satisfactory. (121) 
Dewey seems to offer us a metaphysics in which a mental state (doubt) is ascribed to a situation that is a merging of the natural world and human inquirers who are freighted with beliefs, needs, desires, and psychological makeups. (120) abductive strategy, the strategy of rational Hope; although she all but spells it out. First of all, she isolates Peirce's most general abductive principal: namely, that "the only assumption upon which [we] can act rationally is the hope of success" (W2: 272). The point of this is to establish that even where our claims are verifiable, they may implicate or entail inherently enabling beliefs that are themselves impossible to verify and may be only contingently invoked in any concrete instance. So that when she adds at once that "the principle of bivalence... a regular assumption of inquiry... is something that we have to assume, if we are to inquire into a matter" (50), she goes too far; though she herself demonstrates that this is never quite accurate. She never sorts out what belongs to the pragmatist picture of the world and of what belongs to the world. She herself correctly diagnoses Peirce's account of the logician's "saltus"; but she neglects to specify the mate (in Peirce) to Dewey's account of a "problematic situation." Peirce, as she reports, adds two clarifications at least: first, that "Abduction commits us to nothing. It merely causes hypotheses to be set down upon our docket of cases to be tried" (CP5: 602); and, second, that "[irregularity is] the overwhelming preponderant rule of experience, and regularity only the strange exception" (CP7: 189). But this plainly leads to the concession that not every assertible part of an admissible assertion needs to be itself verifiable; that not every proper part of what is verifiable itself needs to be verifiable; that, generally, what is verifiable implicates abductive beliefs that are never themselves verifiable, though they are needed; and that the practice of uttering truth-claims is "warranted" on the strength of intuitions drawn from accumulating experience that yield regulative "pictures" of the world, that are not themselves verifiable (48-9). ${ }^{4}$

This is extraordinarily close to Dewey's intent. But if it is, then Misak miscasts a would-be corollary to the infinitist lesson of Peirce's fallibilism, which Dewey approaches somewhat more economically (even if "awkwardly"), when she mixes the subjunctive sense of the following pronouncement with an indicative reading of the fallibilist thesis: 
"were a belief to show itself to be forever fit, that belief is true" (25). Correctly formulated, the corollary confirms the ineliminability of the idealist heuristic that Dewey features, which the autonomous "empiricist" realists inevitably slight. You begin to see why the finititist ("realist") account of truth cannot be deprived of the infinitist picture of truth ("idealist," if you please). I take this to be the fuse of pragmatism's most important "epistemological" contribution.

\section{BIBLIOGRAPHY}

DEWEY J., (LW12) (1981-1990), The Later Works of J. Dewey, 1925-1953, Boydston J. A. ed., Southern Illinois University Press, Carbondale and Edwardsville.

MISAK C., (2004), Truth and the End of Inquiry: A Peircean Account of Truth, Oxford, Clarendon.

PEIRCE C. S., (CP) (1931-1958), Collected Papers of C. S. Peirce, 8 vols., Hartshorne C. \& Weiss P. ed. (vols. 1-6), Burks A. ed. (vols. 7-8), Cambridge (Mass.), Harvard University Press.

PEIRCE C. S., (W) (1982-) Writings of C.S. Peirce: a Chronological Edition, 7 vols. published, Fisch M. et al. eds., Bloomington, Indiana University Press.

RORTY R., (1992), The Linguistic Turn: Recent Essays in Philosophical Method, Chicago, University of Chicago Press, 3rd ed.

\section{NOTES}

1. Oxford, Oxford University Press, 2013. In citing Peirce and Dewey, I adopt Misak's policy of standard abbreviation; in fact, for reasons that will become clear, I deliberately rely on the specific texts she draws from each. Hence, in citing passages from her new book - from Peirce or Dewey or from her own views - I simply give the page references in parentheses; references to other texts are given in the usual way.

2. Dewey's texts, taken from Misak's discussion, appear at (LW12: 109-111), cited in (Misak: 120). I take the whole of \$7.4, in The American Pragmatists (six-plus pages) to capture very nearly the essential nerve of Misak's entire argument regarding the right reading of the classic pragmatists.

3. See (Rorty, 1992: Introduction). This must be read together with "Twenty-five Years After," added to the 1992 edition, in which Rorty rejects his own "methodological" (and/or "metaphysical") presumptions about the linguistic turn. I cannot see how this can be read without rejecting Rorty's disjunction between "language" and "experience." There's simply no such thing as linguistic or semantic "autonomy" if that means that philosophy can examine language without viewing language (or logic) as embedded in actual human practices ("experience," in Dewey sense). I expect that Misak's Cambridge Pragmatism (not yet issued) will come back to these questions. In anticipation, I suggest that to grasp the force of Dewey's account entails at the very least the stalemate or defeat of deflationism.

4. See also Misak (2004, Preface). 


\section{AUTHOR}

JOSEPH MARGOLIS

Temple University

josephmargolis455[at]hotmail.com 